\title{
古紙リサイクル抄紙編
}

\section{Used Paper Recycling in the Paper Making Process}

王子マテリア株式会社 技術本部 技術部

山森明浩, 内海 拓

Akihiro Yamamori and Taku Uchiumi

Oji Materia Co., Ltd.

\begin{abstract}
The paper-machine is generally consisted of the headbox, the wire part, the press part, the drier part, the calendar, etc., and each part had simple structure once.

Moreover, since opration of the paper-machine depended on operator's experience, knowledge and intuition concerning about operation method of equipment, it was difficult to get the stable quality of paper and condition of the paper-machine.

However, various research and development and continuous progress of various equipment have caused the drastic improvement of the performance of a papermaking process.

We describe the outline of the structure and principle about each papermaking process.
\end{abstract}

分類 $: \mathrm{S}_{2}$ 板紙の性質一般, $\mathrm{S}_{0}$ その他

\section{1. はじめに}

紙の抄造を行う抄紙機は，一般的にヘッドボックス，ワ イヤパート，プレスパート，ドライヤパート，カレンダ等 より構成されており, かつて各パートの構造は, 極めて単 純なものであった。また設備の取扱方法についても，その 取扱者のいわゆる腕や勘に頼っていたため, 取扱者が変わ れば紙の品質や抄紙機の調子が変わることは普通であった。

しかしながら現在では, 抄紙機の性能は, 研究開発と操 業経験によって飛躍的に向上し, 抄紙機の高速・広幅化, 紙品質の向上, 自動化等がなされ, 生産性を向上させてき た。

今回，板紙を抄造する抄紙工程について，抄紙機各パー ト別に構造と原理の概要を述べる。

\section{2. 抄紙}

抄紙工程は，抄紙機を用いて，主に次に述べる 11 工程 にて，紙を製造する工程である。

1）種箱・原料稀釈系統

2) ファンポンプ

3）除塵器 ※1）～3）をアプローチ系と称する。

4）ヘッドボックス（紙料流出部）

5）ワイヤパート（脱水部）
6）プレスパート（圧搾・搾水部） ※4） 6）をウェットパート（ウェットエンド）と 総称する。

7）ドライヤパート (乾燥部)

8） サイズプレスパート（ゲートロール等コータ含む）

9) カレンダパート

10）リールパート（巻取枠替え部）

11）ワインダ・カッタ

尚，抄紙機の種類は，ワイヤパートの型式によって，長 網式と円網式 (丸網式), 更に実際にはこれらの変形であ る 2 種類以上の組み合わせ(ツインワイヤ,コンビネーショ

ン）の場合もある。またドライヤパートの型式によって多 筒式とヤンキー式に大別される。

吒解, 薬品配合の終わった紙料は濃度 0.5〜 1\% 前後(水 分 99.5 99\% 程度）に稀釈，調整されストックインレッ トからワイヤパートへ噴出され，ワイヤ上で走行しながら， 水はワイヤ下に流出・脱水, さらに吸引・脱水されて, 紙 層を形成していく。

ワイヤパートを出たところで $20 \%$ 程度の紙料濃度（水 分 $80 \%$ 程度）となり，次のプレスパートで，プレスロー ルとフェルトとの間で圧搾・脱水されて，一般的に水分 50〜 60\%（濃度 50〜 40\%）程度に，さらにドライヤパー トで湿紙の水分が 5〜10\%にまで乾燥され紙となる。 
その後，リールパートで所定の長さに巻き取られ枠替え し，リールスタンドへ移す。この段階で上質紙などの非塗 工紙はできあがる。

尚，一般的にドライヤパートの中間部に，紙の表面強度 を上げたり，水やインキに対する浸透性をコントロールす るために表面処理を行うサイズプレスが設置されている。

\section{1 種箱・原料稀䣋系統}

調成室で一定濃度に調成された原料は, 最終的にはマシ ンチェストといわれる完成原料槽に貯えられ，ここからポ ンプで必要量が抄紙機に送られる。種箱はこの原料の受入 用定へッドタンクで，送種量の調整が主な目的である。種 箱はマシン室内のヘッドボックス付近に設置され, ファン ポンプの直前で白水と原料を混合するものが一般的である。

原料は最終濃度調整された後, レベルコントロール（オー バーフローまたはコントロールによる）された種箱に入り， 出口（ファンポンプ手前）に設けられたバルブ (坪量調節 弁）で流量を調整し白水と混合される。このバルブ開度は 紙の坪量を決定する重要な機能を持っている。

\section{2 ファンポンプ}

種箱からの原料とバックウォータは，ファンポンプと呼 ばれる大型の渦巻ポンプで混合される。ファンポンプはこ のような混合作用と, その稀釈原料をへッドボックスに送 り込む機能を持っている。

一般の抄紙機で使われるいくつかの渦巻ポンプの中では 最大である。密閉型ヘッドボックスを使用する最近の高速 マシンでは, ファンポンプの性能に対する要求も厳しく なってきている。

\section{3 除 塵 器}

一般的な抄紙機では，稀釈された原料はへッドボックス の手前で，何らかの方法によって最終的な除塵が行なわれ る。この除塵装置は単純に分けて次の 2 種類になる。

(1) パルプ繊維より重い異物除く装置

(2) パルプ繊維より大きい異物を除く装置

旧式のマシンでは(1)の目的にリフラを，(2)の目的でフ ラットスクリーンを使用してきた。中には紙の種類によっ て1戛設置しない場合もあった。

今日ではパルプ工場の充実したスクリーン装置によって， 繊維塊, 塵, 砂流などの異物が効果的に除去されているこ とが多いので，ヘッドボックス前のスクリーンの意味は激 減しているといえないことはない。しかし，最近の抄紙機 のスピードアップによって，これらの異物が特にウェット エンドの成績に鋭敏に影響するようになってきており，ま た紙の品質に対する要求もより高度化しているため, か えってマシン除塵器の必要性は高くなっているといえる。 マシン前除鹿器の目的は次のようになっており, 今日では (1)の機能を持つ除鹿器として各種の渦流式クリーナが使わ れ，(2)機能を持つものとしては，密閉型のプレッシャス クリーンが使われている。また抄紙機によっては脱気装置 も設置されることがある。

a . 紙の見栄えを損なう塵などの異物の除去

b ．ワイヤを損傷させるような硬い異物などの除去

c . 紙切れや不良紙の原因となる粕やスライム塊など
の除去

d. 繊維の分離作用

2.4 ヘッドボックス（ストックインレット）

抄紙機にとってヘッドボックスは，紙の品質構成上重要 な位置を占め，後の工程に与える影響は大きい。

ヘッドボックスの機能は，前処理工程から原料を受け入れ， 抄紙機幅方向に均等に広げ，地合に悪影響を及ぼす大きさ の乱流やフロキュレーション (凝集)・横流れ等を最小限 に留めて，ワイヤ幅方向に均等なマシン方向のスピードを 持つ流れへと変換することである。

ヘッドボックスは基本的に，ディストリビュータ（紙料 分配機構）と整流装置，スライスによって構成されている。 ディストリビュータは，配管ラインからの流れをマシン全 幅に均等に分配する。整流装置はディストリビュータから の流れを乱流の少ない，一様で安定した流れにする。スラ イスは流れをワイヤスピード近くまで加速し，開度等を調 整して噴流とワイヤの衝突の状態を制御する。

ヘッドボックスの基本的な形式としては，開放型と密閉 型（エアクッション型）の 2 つがあり，高度な品質要求及 び高速化・広幅化の流れの中で，歴史的に開放型から密閉 型へと変化してきた。なかでも最近主流を占める，ハイド ロリック型は密閉型に属する。

\subsection{1 新型のヘッドボックス}

紙の品質評価の基準として，最近重要性を増しているも のに熱カール特性や寸法安定性がある。これらは，紙の繊 維配向と密接な関係があり，そのため新型のへッドボック スでは繊維配向を調整できる機能を備えたものが相次いで 上市されている。

従来型のハイドロリックヘッドボックスは，スライス開 度を幅方向に微調整することで坪量プロファイルを調整し ようとするのが基本的な考え方であった。しかし，スライ ス開度をわずかに変えても抵抗の変化により噴流の速度分 布に乱れが生じてしまい，その結果として横流れが発生， 繊維配向に影響を与えることになる。更に，先にも述べた ようにその部分の坪量だけではなく，両側にまで影響を与 えてしまうことになる。すなわち，従来型のへッドボック スでは，坪量と繊維配向を個別に制御することができない のである。

そこで，新型のヘッドボックスの基本的な考え方は，そ の部分のトータルの流量つまり速度は変化させずに濃度の みを変えるものである。従って，繊維配向への影響を小さ く抑えようという考え方である。これにより,坪量プロファ イルと繊維配向が個別に調整可能となる。

この繊維配向に影響せずに坪量プロファイルの調整が可 能な新型のへッドボックスは，多層抄製品の中でも，その 内の 1 層へ使用され，品質向上に寄与している。

\section{5 ワイヤパート（脱水部）（図 1）}

ワイヤパートでは，ヘッドボックスから噴出した原料の うち，ワイヤ上には繊維分と填料が残り，余分な水分は重 力や各種脱水装置により発生するバキューム圧（負圧）に より脱水され，最終的にはクーチロールで固形分濃度 18\%〜 20\% 程度のシートを形成する。 

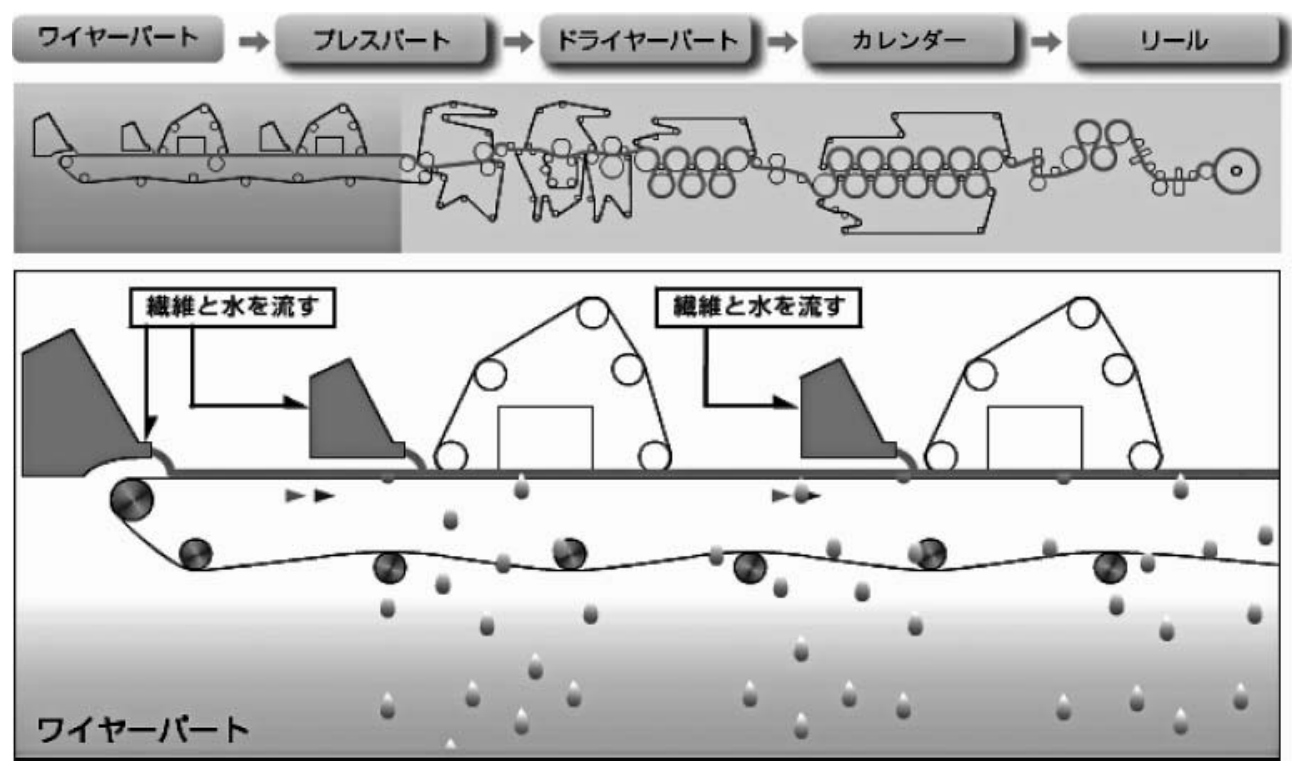

図 1 ワイヤーパート

ワイヤ上の原料の流れや脱水状態が地合・坪量プロファ イル・ $\mathrm{T} / \mathrm{Y}$ 比（縦/横比）・䋊維配向等の変動要因となる ため，紙の品質が決定される重要なパートである。

抄紙機の型式はワイヤパートの構造の差から，長網抄紙 機（フォードリニアマシン）のほかに円網抄紙機や各種の フォーマ（代表例はツインワイヤフォーマであり，別名ダ ブルワイヤフォーマともいう）がある。

\section{a）長網式抄紙機}

1 枚の回転するエンドレスの長いワイヤ（すき網）を持 つ型式の抄紙機を長網式抄紙機というが，ワイヤパートは 原料を脱水し紙層を形成させるところである。紙料はワイ ヤ上を走行し, 初めはテーブルロールやフォイルなどの脱 水パーツで，また脱水が進んでからはサクションボックス， クーチロールなどの真空ポンプを用いた脱水装置によって $20 \%$ 前後の水分を脱水し, 次のプレスパートに送る。ワ イヤは以前までは青銅製（ブロンズワイヤ）であったが, 現在ではほとんどプラスチック製となっている（ワイヤ目 の大きさは一重織りブロンズワイヤで 70 メッシュ相当)。 長網式抄紙機は, 現在最も多く用いられている抄紙機であ るが，問題点が大きく 2 つる。

(1) 紙の表裏二面性の問題

長網抄紙機ではワイヤに積層した繊維を通しての片面脱 水であるため, ワイヤに接しない自由表面と, 接する面で は微細纎維・填料のリテンションが異なり, 密度・平滑 度・繊維配向等に表裏差を生じる。そのため, 印刷時にお けるインク乗りの違い, カール等の問題を起こす場合があ る。

\section{(2) ワイヤ上の自由表面の存在}

ヘッドボックスから噴出した原料がワイヤに衝突する際 の衝撃や速度増加に伴い, 各種脱水装置により発生する無 視できない大きさの正, 負圧に起因したスパウティング (ジャンピング現象）であり，この作用に起因する原料の 乱れは地合や紙層構造等の品質に悪影響を及ぼす場合があ
る。

b）ツインワイヤ式抄紙機

ツインワイヤ式抄紙機は, 上記の長網式抄紙機の欠点(紙 の表裏差，高速化）を解消するため開発されたもので, ギャップフォーマとハイブリッドフォーマに分類される。

(1) ギャップフォーマ

原料は 2 枚のワイヤに挟まれて走行し, 両側にほぼ均等 に脱水するため, 長網式と比べて, 紙の表裏差が少なく, 地合が良い。高速抄紙が可能で, 現在, 新聞用紙やティシュ 用の薄物高速抄紙機 $(1,800 \mathrm{~m} /$ 分）として多く用いられ ている。

(2) ハイブリッドフォーマ

オントップワイヤフォーマとも呼ばれているが，従来の 長網式ワイヤの途中または最後部の上にもう1つのワイヤ （トップワイヤ）を載せて，その部分で上下両方に脱水す る型式である。いわば長網の一部をツインワイヤ化したも ので，ワイヤ上の留まりや紙の地合は良くなり，抄速は ギャップフォーマ式ほど速くはないが $1,300[\mathrm{~m} /$ 分 $]$ 程 度にすることができる。現在，印刷用紙や塗工原紙用抄紙 機として用いられている。

c） 円網式抄紙機

円網式抄紙機は 1809 年に英国のディッキンソンによっ て発明されたもので，その構造は抄槽の中で円網を回転さ せ，それによって円網上に生じた紙料層をクーチロールで フェルト上に吸いつけていくものである。抄速は遅いが薄 物抄造に適し, 純白ロールや衛生用紙（ティシュ）などの 製造に用いられている。また，円網を多数ならべて，それ らの原料を順次吸いつけていくと多層に抄き合わせた紙を 作ることができ，古くから板紙用抄紙機として用いられて きた。

尚，最近は高速化のニーズから，すき網部に短いワイヤ を使った短網式のものや長網上に複数のワイヤを載せたも のが開発され，さらには円網，短網，長網の組み合わせた 
コンビネーション抄紙機が実用化し, 紙の種類や要求に応 じて使われている。

d） 多層抄き（抄合わせ）フォーマ

板紙のような厚物の抄造には，数台の丸網・長網を組み 合わせた多層抄き（抄合わせ）フォーマが主流である。

通常，ワイヤの数だけヘッドボックスも用意されており， 各々脱水された後抄合わされる。また，脱水形成された原 料層の上に別の原料を乗せ，その後オントップフォーマで 上方脱水されるものもある。更に，1つのへッドボックス から異なった種類の原料ジェットが同時に出て, ギャップ フォーマ，ハイブリッドフォーマで脱水されたりする多層 抄きフォーマも開発されている。

多層抄きは，薄いシートを重ねることができ，また各層 に異なった原料を使えるので，最終目的に合わせて紙の特 性を自由に構成できる利点がある。

\subsection{1 地合形成因子について}

抄紙機において，紙の地合形成を支配するワイヤパート のコントロールは重要であり，他の基本物性にも大きく影 響を与える。一般的に良い地合とは，纎維や填料が均一に 分散し，紙を透かしてみたときに，むらの無い紙層の状態 をいう。

ワイヤ上に噴出された原料の動きは，次のような因子の 影響を受け, 地合を変化させることから, 重要な基本ファ クターである。

(1) 抄速

(2) 原料ジェットの落下位置

(3) 原料の濃度・表面張力・粘度

(4) ワイヤ上での原料層の厚さ

(5) ワイヤテンション

(6) 各脱水装置の配列

\section{6 プレスパート（圧搾・搾水部）（図 2）}

ワイヤパートから出てきた $80 \%$ 前後の水分を持った湿 紙を，数組のロールとフェルト（毛布）を介して，機械的
に圧搾脱水するとともに，ワイヤマークなどを減らし紙質 を向上するためのセクションである。

繊維は保水性が高いため，プレスパートでの機械的脱水 には限界があるが，湿紙をフェルトに載せて数組（3〜4 組）のプレスロールの間を通して圧搾し 50〜 60\%の水分 率になるまで脱水する。

プレスロールには表面を研磨し滑らかにしたプレーン ロール（ストーンロール…花崗岩）と，プレーンロールだ けでは脱水が不十分なため，表面に円周方向の溝を付けた グルーブドロール（溝付きゴム被覆ロール）や，ロール内 部に吸引箱（サクションボックス）を持ち，水分を吸引す るために表面に穴が開けてある真空サクションロールなど がある。実際にはそれら組み合わせて使用される。板紙に おいても最近ではシュープレスが主流となっている。

2.6.1 シュープレス

ロールニップ脱水のニップ圧分布は，ニップ中心で急激 に圧力が高くなり，衝撃ニップとなる。このような現在の ロールニップによる脱水では, 抄紙機の高速化に伴い, ニッ プ圧の増大により，次の問題が発生する。

(1) 紙の嵩の減少

(2) 紙の両面性の悪化と, Z 方向の紙層構造の不均一化

(3) クラッシングの増加（脱水圧の急激な上昇による砕 け)

(4) フェルトの保水能力の低下と寿命の短縮（フェルト 復元力の低下)

(5)ロールの磨耗による研磨頻度の増加

(6) グルーブドロール脱水量の減少（高圧ニップ化によ る溝つぶれ)

しかしながら，高坪量の板紙においては，シートドライ ネスの向上と蒸気の削減のため，シュープレスが多く用い られている。その結果，プレスセクションでのニップ圧の 増加により，シートの密度が上がり，強い強度を持つよう になった。このような経緯から，ロールニップ脱水に代わ
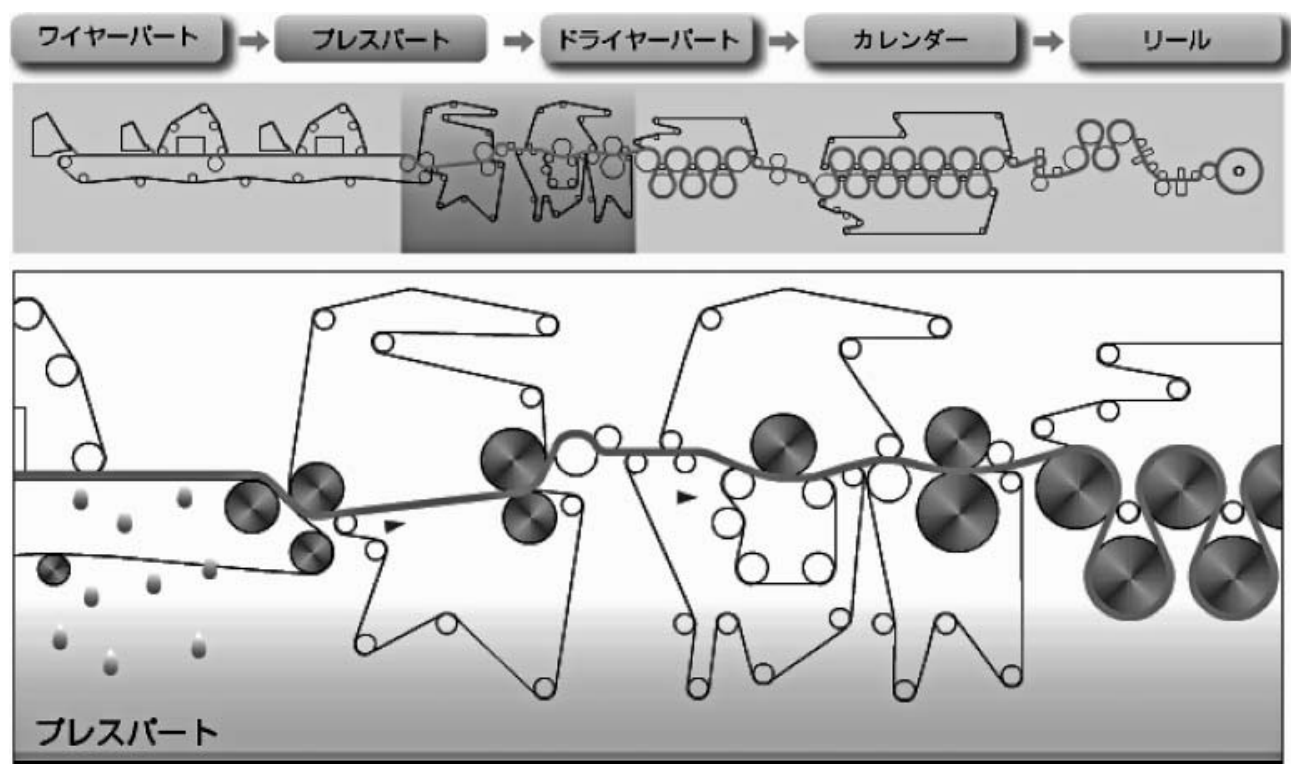

図 2 プレスパート 
る脱水方法としてシュープレスが注目されてきた。

シュープレスはロールプレスに対し, 次のような特長を 持っている。

(1) ニップ幅が広い

(2) 高いニップ圧設定が可能

(3) 緩やかなニップ圧増加を設定できる。

この他にシュープレスを上質紙に適用するためには次の 条件が必要である。

(1) 駆動動力が小さい

(2) 高速回転に耐える

(3) ニップ圧プロファイルを可変とする。

\section{7 ドライヤパート(乾燥部)（図 3)}

これまでに述べたワイヤパート，プレスパートの過程で はそれぞれ自然濾水，真空吸引及び加圧によって脱水が行 なわれるが，その最終湿紙水分はロールプレス $52 \%$, シュープレス $45 \%$ と 52〜 45\% 程度が限界であるとされて いる。そのため，これ以上の水分除去は加熱蒸発によらざ るを得ない。ドライパートはこの目的のために設けられる。 いかなる抄紙機であっても，シートから同量の水分を除 去するのに要する費用は，プレスの圧搾と加熱蒸発では後 者の方がはるかに高価である。

熱はドライヤシリンダへ送られる蒸気によって供給され， シートから蒸発した水は循環空気によって排出される。排 出空気は湿度が高いが，温度も高いので，この熱量を一部 回収して，ドライヤフード吹込み用の乾燥空気を過熱した り，水を加熱して抄紙機において有用な温水をつくること もある。このように，ドライヤパートの熱効率を向上させ る目的で，排熱回収設備を設ける場合が多い。

尚，ドライヤパートには，大別して多筒式ドライヤとヤ ンキードライヤの形式がある。

a）多筒式ドライヤ

プレスパートを出た湿紙はカンバスで保持して数十本の ドライヤ表面に接触させ，水分を蒸発させて 5 〜 $10 \%$ の製
品水分まで乾燥する。

ドライヤは直径 $1.2 \sim 1.8 \mathrm{~m}$ の鋳鉄製シリンダーで，低 圧の蒸気を吹き込み，凝縮水を排出する構造になっている。 効率良く乾燥するため，ドライヤパートは密閉フードを付 けることが多く，給気は排気と熱交換して供給しフード内 の温度を高めている。また湿った空気の溜りやすいポケッ 卜部には別に熱風を吹き込み，換気と乾燥の促進を図って いる。

b）ヤンキードライヤ

ティシュや片艶包装紙は，ヤンキードライヤと呼ばれる 直径 3〜 $5.5 \mathrm{~m}$ で表面が鏡面仕上げされた 1 本のドライヤ で乾燥が行われるので，このドライヤを持つ抄紙機はヤン キー抄紙機という。

プレス工程を出た湿紙は，ヤンキードライヤに張りつけ て乾燥させるので，片面だけ艶のついた片艶紙になる。ま た，ティシュの場合はクレーピングドクターで紙を掻き取 るので，20〜30\%のクレープのついた紙となる。

\section{8 サイズプレスパート}

サイズとは，主に紙の表面に耐水性を与えインキが滲ま ないようにする処理，またはその目的のために使用される 薬品のことをいう。その処理方法としては内添と外添の 2 つの方法があり，内添は原料・白水系統でパルプに添加す る方法であり，外添は紙の表面に塗布する方法である。こ の外添サイズに用いられる設備をサイズプレスといい，一 般的には澱粉粒子を用いてシートの表面空隙を充填するこ とによって，水の浸透速度を減少させる。

サイズプレスには，2ロールタイプが多いが，抄紙機の 高速化にともなう，ロールポンド部でサイズ塗布液が飛び 跳ね，いわゆる沸騰状になるボイリング現象が著しくなる などの問題が生ずるため，近年，ゲートロール型やロッド メタリングタイプが採用されるようになった。

サイズ液塗布後は，さらに乾燥するためのドライヤが必 要であり，サイズプレス前のドライヤをメインドライヤ，

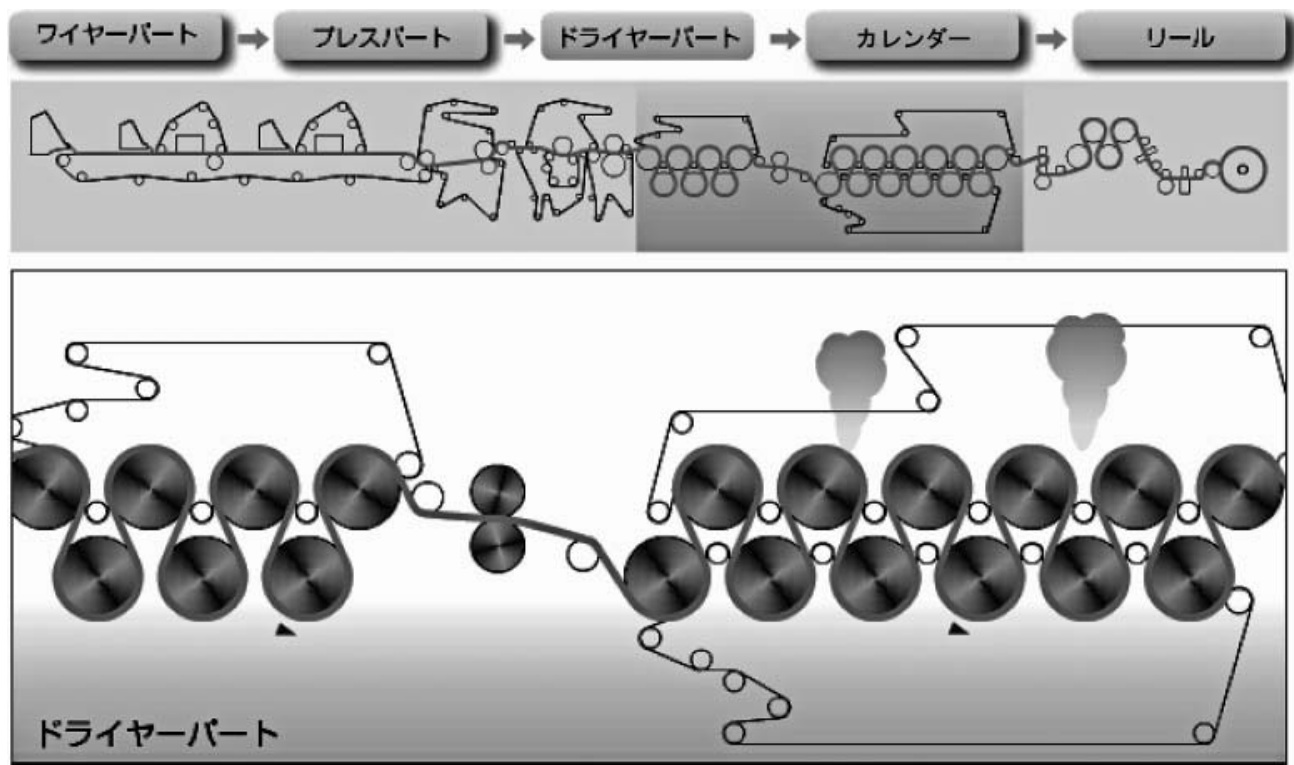

図 3 ドライヤーパート 
サイズプレス後をアフタードライヤと呼ぶ。

a） 2 ロールタイプ

2 本のゴムロールの間に紙を通し形成されるニップ部に 塗布液（サイズ液）を供給し，ポンドと呼ばれる塗液溜り を作り，いわゆるドブ漬けすることによって紙の両面にサ イズ液を塗布する表面サイジング装置である。

液濃度は 3〜6\% と低い。型式には垂直型（バーチカル 型), 水平型（ホリゾンタル型）および傾斜型（インクラ インド型）があり，主流は傾斜型である。サイズプレスは 塗布濃度が低いため, 後述のゲートロール型よりは紙の乾 燥に多くの熱量が必要である。しかも, マシン速度が速く なるにつれ，ポンド部で塗布液が飛び跳ね，いわゆる沸騰 状になるボイリング現象が発生し, 抄速アップ $(1,000$ m/ $\min$ 以上）が困難である。

尚, 表面サイズ剤としては主に澱粉, ポリビニルアルコー ル（PVA）やポリアクリルアマイド（PAM）などが使わ れている。

b） ゲートロール型（ゲートロールコータ）

サイズプレスのポンド (含浸法) 方式に対して転写方式 が採用されるようになった。その典型がゲートロールコー タである。これは前記の高速化にともなうボイリング現象 対応と塗布液濃度が高くできるため省エネの面から適用さ れるようになってきた。ゲートロール型は 10～20\%くら いの高い濃度の液が塗布できるロール塗工装置のー種で, 本体は 6 本のロール (片面 3 本) で構成され, 塗液はロー ル表面で被膜を形成し，この被膜を紙に転写する形で紙の 両面に同時塗工される。

近年，印刷用紙や塗工原紙，新聞用紙など多くの品種に 採用されるようになったもので，オンマシンコータとして 上質紙などの非塗工紙に澱粉，PVA や PAM な゙の表面 サイズ剤を塗布する表面サイジングばかりでなく，顔料や ラテックス，澱粉などを配合した塗料を塗布するコータと して活用され微塗工紙分野にも適用されている。その塗布
量は片面で 0.5 10 g/ $\mathrm{m}^{2}$ 近くまでの広い範囲で塗工され る。

また，サイズプレスに比べ，塗布液が高濃度のため，紙 の中に浸透するよりも紙表面に塗工膜として残る。いわゆ る転写塗工であり，そのためゲートロールコータは微塗工 紙製造等を含めて紙表面の改質を行いやすい。

一方，サイズプレスは低濃度でポンド方式のため塗布液 が紙の中に浸透しやすく，紙の層内強度を上げやすい。

ゲートロールコータでは，紙匹（ウェブ）と同速で回転 するアプリケータロール間で紙は面圧を受け，塗工される が，塗布量は塗布液の濃度，速度，ニップ圧，各ロールの 速度比，ロール硬度などによって決まる。また，塗布液は ファウンテンロール（アウターゲートロール）とメタリン グロール（インナーゲートロール）との間に供給され，そ こでポンドを形成し，メタリング(計量)され，アプリケー タロールに転写される。そのためにボイリング現象がなく 2 本ロールサイズプレスより高速運転が可能である。

\section{9 カレンダパート（図 4)}

ドライヤパートを出た紙は，表面が荒く，組織も若干ソ フトであり，このままでは見栄えも悪く，印刷性も良くな い。このため表面を滑らかにし，組織を緻密にして所定の 紙厚にする目的でカレンダが使用される。

従来のカレンダは，チルドロール(鋳鉄製) を 2〜4段 積み重ねて加圧したり，6段積み重ねてロール自重で徐々 にニップを掛ける方法が一般的であった。どちらの場合で も温度とニップ圧によるアイロン効果で平滑度を改善する。 この方法の欠点は，平滑度を上げるためにはニップ回数ま たはニップ圧を上げるため，紙嵪が減少し紙の弾力が失わ れ，厚みむらの部分が斑点状の光沢むらとして発生する欠 点をもっている。

これらを解消する目的で最近は, ソフトカレンダが注目 されている。ソフトカレンダは弾性体を被覆したクラウン コントロールと加熱したヒーティングロールのニップ間に

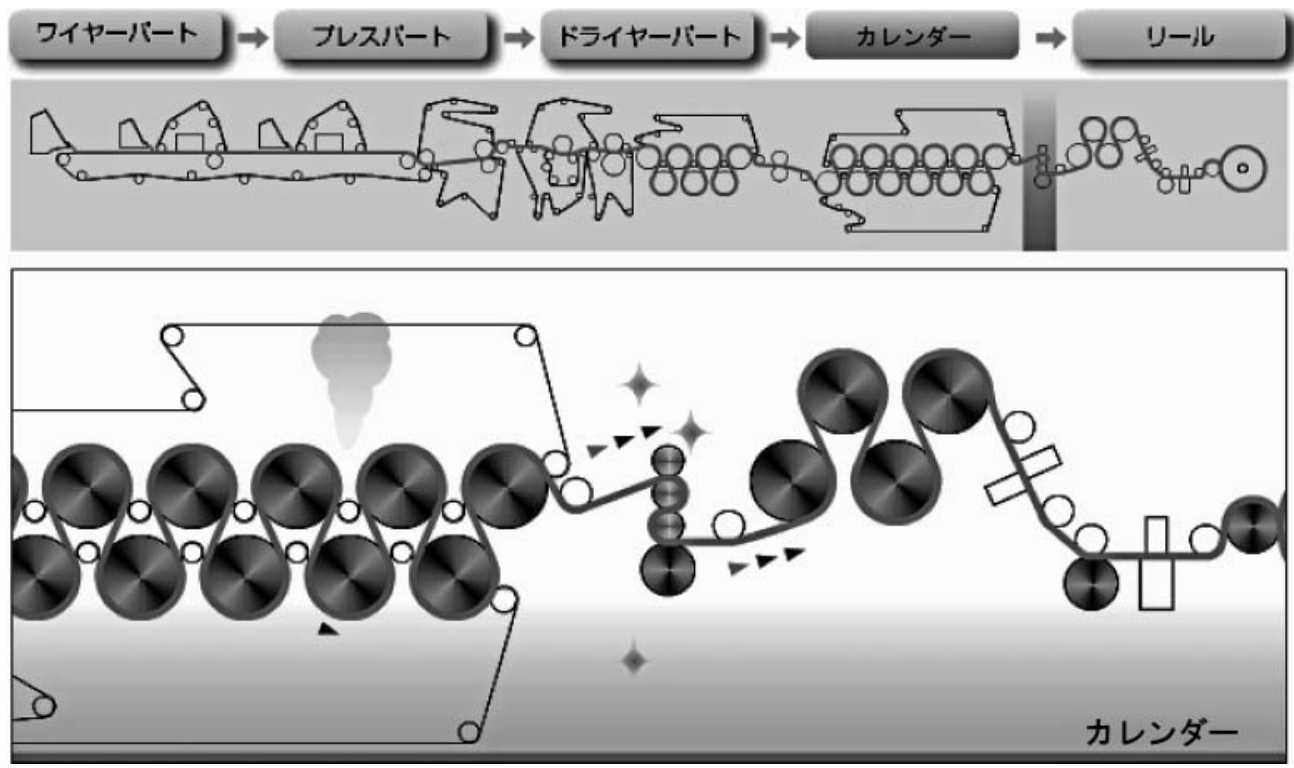

図 4 カレンダー 
通紙することにより，表面の緻密で高平滑な高の減りの少 ない，しかも斑点状の光沢むらの少ないソフトに仕上げら れた紙になる。すなわち印刷適性として欠くことのできな い低密度, 高平滑, 高光沢のある紙を生産できる設備であ る。

\subsection{1 カレンダで発生する品質上の欠陥}

a) バーマーク

マシンの操業条件によっては, カレンダ通過後の紙面に バーマークといわれる，多数の横縞が発生することがある。 この問題はカレンダを使用する上で紙の商品価值に大きく 影響するため重要な問題である。バーマークが発生すると ロールが振動し，音を発生させるので分かり易い欠陷であ る。バーマークは様々な要因より発生するため, 完全に原 因を究明することは大变難しい。従って機械的な要因と, 紙自身のもつ特性から原因を追究する必要がある。

b）幅方向の厚薄不良

坪量, 水分, 塗布量が BM 計によって流れ方向, 幅方 向ともに制御された紙が，カレンダニップに入る。しかも カレンダロールのゾーンコントロール制御，キャリパ幅方 向制御のアクチュエータの発展に伴い幅方向の厚薄不良の トラブルは，最近大幅に減少した。

c) 型 付き

紙に付着した異物がカレンダでニップされ，カレンダ ロールに剥ぎ取られ，ロール表面に異物が付着する。付着 した部分だけがロール径が大きくなり，他所とは異なり高 いニップ圧が集中的に掛けられる。このため異物の形通り の強光沢な部分が，ロール周長のピッチで欠陥して現れる。 この欠陉を型付きと呼んでいる。

大きな型付きは欠陥検出器で周期欠陥として検出できる が，小さな型付きは検出できず，人間による斜光検視でし か見つけることができない。従ってロールから異物を取り 除かない限り，連続して発生し続ける性質の欠陥である。
2.10 リールパート（巻取枠替え部）（図 5）

カレンダで光沢を付けられた紙は，この後方に設けられ た巻取機（リール）によって連続的にスプールに巻取られ る。必要な長さに巻取られたリール巻取は，通紙中に別の スプールと入替えしなければならない。通常これを枠替え 作業という。

\subsection{1 ワインダ・カッタ}

リールを降りた親巻取は, 次の仕上げ工程に送られて最 終製品となる。巻取の場合はワインダであり，平判の場合 はカッタである。従って, 紙品質の良否はまずリールで判 定され，常にしかも速く改善のアクションをとらなければ ならないので，平常作業では最も注目すべきパートである。

リールで巻取られた巻取は, クレーンで吊り上げること なくアンワインダ部へ自動搬送し，また巻取終了後スプー ルをリールへ返送する。こうした自動化装置が用いられる のが一般的である。

\section{3. 抄紙工程における各種制御}

抄紙機において製品を製造するにあたっては，次のよう なセンサ，制御を用いて操業管理・品質管理が行なわれる。 以下に，センサ及び制御の一般的な例を示し概略を説明す る。

\section{1 抄紙工程のセンサ}

\subsection{1 坪 量 計}

紙の品質を評価する尺度の一つに，紙 $1 \mathrm{~m}^{2}$ あたりの重 量すなわち「坪量」がある。この坪量を測定するセンサの 測定原理にはいくつかの種類があるが，最も一般的な測定 方法は， $\beta$ 線透過吸収方式である。

この坪量センサでは測定される紙を透過する放射線の減 衰量から坪量を測定する。

\section{1 .2 水 分 計}

紙に含まれる水分率も，紙の品質を評価するための重要 な尺度の一つである。この水分率を測定する水分センサの

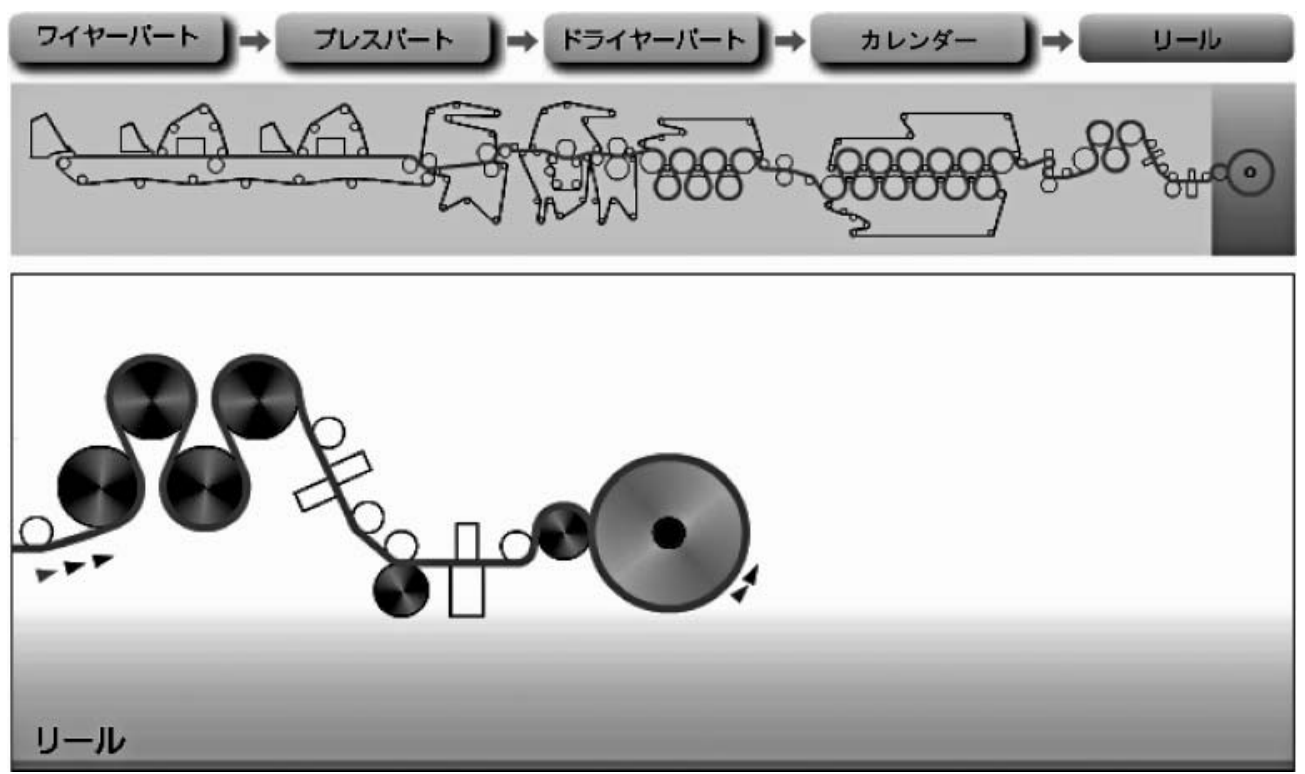

図 5 リール 
測定原理には，一般的に近赤外線方式と，マイクロ波方式 とがある。

近赤外線方式は，特定の波長光の近赤外線が紙中の水分 に吸収される原理を利用したものである。一方マイクロ波 方式は, 1,000〜 30, $000 \mathrm{MHz}$ のマイクロ波と呼ばれる, 特 に水分によく吸収される電磁波を利用したものである。

\section{1 .3 キャリパ計}

紙の厚さを測定するセンサで，上下センサのいずれか, もしくは両方が可動式になっている。各々のセンサは，紙 を挟み込む形でセンサ間の距離を測定している。紙厚が増 減すると上下センサ間の距離が変化し，この変化が紙厚の 変化として捉えられる。測定は電気的に行われるのが一般 的である。

\subsection{4 カラーセンサ}

坪量, 水分, 紙厚だけではなく, 紙の色彩に関する品質 要求も高まっており, 紙のカラー測定も標準化されつつあ る。

カラーセンサは分光測色方式と光電色彩計による方式の 2 通りがあるが, 通常前者を测定原理としている。光源は キセノンランプまたはハロゲンランプを使用し, 紙に対し て $45^{\circ}$ の角度で照射する。紙から反射される光のうち, 垂 直方向の光だけ集光し, 分光波長の光量を, スリット, 屈 折格子による分光後, リニアフォトダイオードで受光し, 電気信号に変換する。この信号をマイクロプロセッサで, 波長の反射率データとした上で, スペクトル 3 刺激值とし て計算する。

\section{1 .5 灰 分 計}

紙に含まれる灰分（クレー，タルク，カオリン，酸化チ タン, 炭酸カルシウム等) をオンラインで測定するセンサ であり，X 線透過吸収を利用している。

\section{2 抄紙の各種制御}

\subsection{1 抄速銘柄変更制御}

抄速銘柄変更制御は操業条件変更時の過渡制御であり, 製品品質を変えずに生産量を調整するための抄速変更制御 と，製品銘柄切替時の損紙を最小に抑えるための銘柄変更 制御がある。

抄速銘柄変更制御は，BM 計で目標抄速を設定し，坪量， 水分率, 灰分率, $\mathrm{J} / \mathrm{W}$ 比等の製品品質を一定に保つよう に，ドライブ装置への抄速変更命令と連動して予測值演算 制御を行なうフィードフォワード制御と, 制御中のプロセ ス外乱に対して補償制御を行なうフィードバック制御を組 合わせて実現されている。

一方，銘柄変更制御は，通常 BM 計に銘柄マスターデー 夕として登録されている坪量, 水分率等のデータを読み出 し, 次銘柄として設定し, 各制御量に対して予測值演算を 行い短時間で次銘柄品質へ移行するように制御を行う。抄 速変更制御と同様にフィードフォワード制御と, フィード バック制御を組合わせた制御が行なわれる。

\subsection{2 カラー制御}

紙のカラー (色彩) に関しては従来, ラボ值, または BM 計でのカラー測定值をオペレータが監視し, 必要に応じて 染料の添加量を加減して制御を行なってきた。
このカラーの自動制御は, BM 計に搭載したカラーセン サからの信号を，各々の設定值と比較し，偏差を最小にす る制御である。設備は一般的に 3 種類またはそれ以上の染 料を一定濃度に稀釈後, ミキシングタンクで基礎染料とし て添加，ファンポンプのサクション側で補色染料として添 加している。カラー制御では補色染料の添加量を操作して 制御する。

\subsection{3 坪量幅方向制御}

幅方向の坪量制御は製品の品質を保つ上で最も重要な制 御の一つであり, 現在マシンの標準装備品の一つである。

本制御は一般的に BM 計にて幅方向の坪量を測定し, 演 算後にアクチュエータでスライスリップの開度を変えるこ とにより制御を行なっている。しかし，リップ開度のばら つきによるワイヤ上での原料の横流れや，マシン速度，坪 量, $\mathrm{J} / \mathrm{W}$ 比, 紙の収縮率, 紙料温度の変化によるスライ スリップの歪み等の外乱, 干渉が多いため, 測定点と操作 点の位置対応もとりにくく, 制御演算も複雑である。

最近では，スライスリップの開度を変えずジェット速度 が幅方向に均一な, 纎維配向や隣接のスライスリップへの 干渉も少ない濃度調整式による制御が主流となっている。

\section{2 .4 水分率幅方向制御}

幅方向の水分率を均一にする目的で幅方向制御が導入さ れている。水分率のばらつきはカレンダでの紙厚制御や, 製品の平滑度, 光沢度にも影響を及ぼすため, 幅方向の水 分率制御は製品の品質管理に重要な役割を持っている。

紙の流れ方向の水分率制御はドライヤでの蒸気圧力を設 定するのに対し, 幅方向制御はプレスでの加温脱水促進, ドライヤでの加湿, ドライヤ出口での加熱乾燥の 3 通りの 方法がある。

いずれも幅方向に設置されたアクチュエータを操作して 制御するが，アクチュエータの選定にあたっては，抄物・ マシンの仕様や設置スペースを考慮の上選定される。操作 流体の種類としては蒸気, 水, 赤外線が用いられており, 空気を補助として利用するものもある。

\subsection{5 キャリパ幅方向制御}

キャリパ計によって測定された情報をもとに，設定され た厚さに紙厚偏差を修正し，均一な紙厚に制御を行なう。 通常 2 本のロール間を通過させ，片側の金属ロール（カレ ンダロール）を幅方向に何ゾーンかに区切り，ロールの各 ゾーンを熱，または油圧によって膨張，収縮させ紙の凸部 を変形させたロールで押しつぶす形で，整形を行なう。

\subsection{6 欠陥検出装置}

紙の穴, 異物を検出するセンサとして欠陥検出器がある。 センサとしては, 古くは太陽電池などの単純な受光素子を 用いたものが使用されていたが，最近では CCD イメージ センサを使用するのが一般的であり，抄紙機の高速，広幅 化に対して，高速スキャン，多ビット化が図られている。

\section{4. おわりに}

抄紙においては，抄紙機各パートを経て製品を造ってい る。その中で様々な操業上の諸問題や, 製品の品質管理の ために，多くのセンサや制御を用いている。 
これらをいかに操作し，管理するのかは，抄紙掞いて重 要なノウハウといえる。このノウハウを含め, 抄紙技術の 発展は, 学術的な技術と共に, 操業の経験やそれに基づく 工夫を元に日々進化をしている。

近年，古紙のリサイクルが地球環境問題に対する関心と 共に，コストの面からも多様化している。そうした中で, 古紙をリサイクルするための技術も日々進化を遂げ，今日 の製紙業界を支える一つの要因となっていることは，前回 に述べた古紙の需要や，原料に占める古紙の割合からも明 確である。

このため今回は，古紙より造られた原料が，抄紙機の各
パートでどのような処理が行なわれ，製品となるのかにつ いて概略を説明した。またその製造工程の中で起きる問題 や，必要となる管理を行なうセンサや制御についても，一 般的なものを取上げて説明した。

次回の内容については, 板紙における最新ニーズと今後 の方向について説明したいと思う。

\section{References}

1）王子製紙株式会社：「紙・パルプの実際知識」 $\mathrm{p} 43-54$ (2001)

2）紙パルプ技術協会：「紙の抄造」 p 1-383, p 459-473 (1998) 